\title{
The effects of Pediococcus acidilactici and Saccharomyces cerevisiae on broiler chickens challenged with Clostridium perfringens induced subclinical necrotic enteritis
}

\author{
Rachid Merati ${ }^{1 *}$, Ali Alaa Abdel-Fattah Mohamed ${ }^{3}$, Zahra Berrama ${ }^{2}$,Hebib Aggad ${ }^{1}$, \\ Abdelhamid Hammoudi ${ }^{1}$, and Soraya Temim ${ }^{2}$ \\ ${ }^{1}$ Laboratory of Hygiene and Animal Pathology, University of Tiaret, Algeria \\ ${ }^{2}$ Laboratoire de Recherche «Santé et Production Animales», Ecole Nationale Supérieure Vétérinaire, Alger, Algérie \\ ${ }^{3}$ Veterinary Serum and Vaccine Research Institute, Cairo, Egypt
}

MERATI, R., A. A. A.-F. MOHAMED, Z. BERRAMA, H. AGgAD, A. HAMMOUDI, S. TEMIM: The effects of Pediococcus acidilactici and Saccharomyces cerevisiae on broiler chickens challenged with Clostridium perfringens induced subclinical necrotic enteritis. Vet. arhiv 91, 389-397, 2021.

\section{ABSTRACT}

The objective of this study was to evaluate the effects of Pediococcus acidilactici (P. acidilactici) and Saccharomyces cerevisiae (S. cerevisiae) on the growth performance, intestinal lesions and ileal Clostridium perfringens $(C$. perfringens) count of broiler chickens challenged with $C$. perfringens induced sub-clinical necrotic enteritis (NE). A total of 150 broiler chicks, allocated into five treatment groups ( 6 replicates of 5 chicks/cage), were reared in cages for 29 days: T0 (control group, not infected, not supplemented); T1 (infected with C. perfringens, not supplemented); T2 (infected with $C$. perfringens and coccidia, not supplemented); T3 (infected with $C$. perfringens and coccidia, supplemented with $P$. acidilactici); T4 (infected with $C$. perfringens and coccidia, supplemented with $S$. cerevisiae). The parameters analyzed were: body weight gain, feed intake, feed conversion ratio, mortality, intestinal lesion score and ileal C. perfringens enumeration by quantitative real-time PCR. The challenge resulted in impairment of growth performance, increased lesion score $(\leq 2)$ and overgrowth of the $C$. perfringens population. However, the dietary inclusion of $P$. acidilactici or $S$. cerevisiae caused a significant improvement in feed conversion, net reduction of gut lesions, as well as a decrease in the intestinal $C$. perfringens population. In conclusion, these results suggest that dietary supplementation with probiotics ( $P$. acidilactici or S. cerevisiae) could be beneficial to alleviate the negative effects of subclinical NE in broiler chickens.

Key words: Clostridium perfringens; necrotic enteritis; Pediococcus acidilactici; Saccharomyces cerevisiae; broiler chickens

\section{Introduction}

The use of antibiotics as growth promoters appeared during the era of industrialization following the Second World War (JUKES et al., 1956). Since then, these antibiotics have been added to the rations of industrial livestock to promote the maintenance of overall health, prevent certain infectious diseases, but also for economic purposes to promote growth and improve feed efficiency (VAN IMMERSEEL et al., 2009).

\footnotetext{
*Corresponding author:

Dr Merati Rachid, DVM, MVSc, PhD, Veterinary Sciences Institute, University of Tiaret, BP P 78 Zaâroura 14000, Tiaret, Algeria, Phone:+213 670 284 000; Fax: +213 46220 079; E-mail: drmerachi@yahoo.fr
} 
However, the large-scale and continuous use of antibioticsinanimal feed is notwithoutconsequences and this practice has raised concerns about the risk of the emergence of bacterial resistance (O'BRIEN, 2002). In January 2006, the European Commission banned the use of antibiotics as growth promoters (feed additives regulation 1831/2003/EC).

Following the withdrawal of antibiotics in poultry feed, European producers have observed the recrudescence of necrotic enteritis (NE) in poultry farms, an intestinal disease caused by the bacterium C. perfringens (TIMBERMONT et al., 2011). This disease has become an emerging global problem, especially in the subclinical form, as a result of the various degrees of intestinal dysfunction leading to poor feed conversion and impairment of body weight gain, which result in a drop in poultry breeding production and cause dramatic economic consequences for the industry (SKINNER et al., 2010; CALY et al., 2015).

A recent study examined the effect of antibiotic withdrawal from feed on the health and production performance of a broiler farm (GAUCHER, 2016). These authors demonstrated that it is possible to produce broilers without antibiotics. However, zootechnical and economic performance remained below those measured in broilers reared with antibiotic growth promoters. The main problems were related to NE.

The scientific community has worked widely in recent years to identify alternative strategies that can be used to replace these growth promoters, in order to ensure control of NE in broiler flocks (HUME, 2011). Previous experiments reported that certain lactic acid bacteria and probiotic yeasts could play an important role in reducing the negative effects of NE in broiler chickens and improve growth performance (EECKHAUT et al., 2016; ZHOU et al., 2016; XUE et al., 2017). However, information on how two different probiotics ( $P$. acidilactici and $S$. cerevisiae) can affect growth performance, intestinal health and the evolution of the intestinal C. perfringens population in broiler chickens challenged with $C$. perfringens induced $\mathrm{NE}$ is limited.
Therefore, the aim of this study was the evaluation of the effects of $P$. acidilactici and $S$. cerevisiae on growth parameters, NE lesions, and the multiplication of $C$. perfringens in the gut of broiler chickens experimentally challenged with $C$. perfringens associated with Eimeria spp. as a coinfection.

\section{Materials and methods}

Birds, husbandry and treatments. A total of 150, 0-day-old, unsexed broiler chicks (Cobb 500), purchased from a local hatchery, were used in this experiment. The birds were individually weighed and allocated to 30 cages (five chicks in each cage), then they were randomly assigned into 5 groups according to the treatments, with 6 replicates in each group and 5 chicks per replicate ( 6 cages per group). The ambient temperature was maintained at $33^{\circ} \mathrm{C}$ for the first 3 days and gradually decreased by $2^{\circ} \mathrm{C} /$ week until the end of the experiment. The lighting schedule was 24 hours light throughout the experiment. The chicks were fed starter diets from day 0 to 15 , and grower diets from day 16 to 28 (Table 1). The diets were formulated in mashed form. Feed and water were provided ad libitum. This research was performed in accordance with the guidelines for the care and use of laboratory animals, approved by the scientific council of the Superior National Veterinary School of Algiers, Algeria.

The birds received the following treatments: T0 (control group): basal diet with no treatments; group T1: basal diet with no additives $+C$. perfringens challenge; group T2: basal diet with no additives $+C$. perfringens challenge + anticoccidial vaccine (overdose); group T3: basal diet supplemented with $100 \mathrm{mg} / \mathrm{kg}$ of $P$. acidilactici (BACTOCELL ${ }^{\circledR}$; Lallemand Animal Nutrition S.A., Blagnac, France) for the whole trial period $+C$. perfringens challenge + anticoccidial vaccine (overdose); group T4: basal diet supplemented with $100 \mathrm{mg} / \mathrm{kg}$ of $S$. cerevisiae (LEVUCELL ${ }^{\circledR} \mathrm{SB}$; Lallemand Animal Nutrition S.A., Blagnac, France) for the whole trial period $+C$. perfringens challenge + anticoccidial vaccine (overdose). 
R. Merati et al.: The effects of Pediococcus acidilactici and Saccharomyces cerevisiae on broiler chickens challenged with Clostridium perfringens induced subclinical necrotic enteritis

Table 1. Composition of the basal diets.

\begin{tabular}{|c|c|c|}
\hline & $\begin{array}{c}\text { Starter diet }(\%) \\
0-15 \text { days }\end{array}$ & $\begin{array}{c}\text { Grower diet }(\%) \\
16-28 \text { days } \\
\end{array}$ \\
\hline \multicolumn{3}{|l|}{ Ingredient } \\
\hline Corn & 60.4 & 60 \\
\hline Soybean meal & 30 & 33 \\
\hline Wheat bran & 5 & 2.5 \\
\hline Soybean oil & 1.00 & 0.50 \\
\hline Dicalcium phosphate & 1.60 & 2 \\
\hline Sodium bicarbonate & 1.00 & 1.00 \\
\hline Premix $^{\mathrm{a}}$ & 1.00 & 1.00 \\
\hline \multicolumn{3}{|c|}{ Calculated nutrients level } \\
\hline Energy $(\mathrm{Mj} / \mathrm{kg})$ & 14.12 & 13 \\
\hline Crude protein & 22.9 & 23 \\
\hline Crude fiber & 8.6 & 8.7 \\
\hline Crude fat & 3.4 & 3.2 \\
\hline
\end{tabular}

a Vitamin mix is supplied in the following per $\mathrm{kg}$ of diet: vitamin A, $1000000 \mathrm{mg}$; vitamin D3, $200000 \mathrm{mg}$; vitamin E, $2000 \mathrm{mg}$; vitamin B1, $150 \mathrm{mg}$; vitamin B2, $500 \mathrm{mg}$; vitamin B12, 2mg; vitamin K3, 200mg; vitamin PP, $2500 \mathrm{mg}$; pantothenic acid, 2500 $\mathrm{mg}$; folic acid, $100 \mathrm{mg}$; biotin, $10 \mathrm{mg}$; choline chloride, $35000 \mathrm{mg}$; methionine, $150000 \mathrm{mg}$; antioxidant, $10000 \mathrm{mg}$; Fe, $6000 \mathrm{mg}$; Cu, 750 mg; Zn, 6000 mg; Mn, 105000 mg; I, 150 mg; Se, 30 mg; Co, 60 mg.

Table 2. Details of oligonucleotide primer sequences used in this study

\begin{tabular}{|c|c|c|c|}
\hline Product size $(\mathrm{bp})$ & Sequence & Primer & Gene \\
\hline \multirow{2}{*}{402} & GTTGATAGCGCAGGACATGTTAAG & $\mathrm{F}$ & \multirow{2}{*}{$\begin{array}{c}\text { Cpa } \\
\text { ( } \alpha \text { toxin) }\end{array}$} \\
\cline { 2 - 3 } & CATGTAGTCATCTGTTCCAGCATC & $\mathrm{R}$ & \\
\cline { 2 - 3 }
\end{tabular}

Experimental challenge. The experimental induction of $\mathrm{NE}$ in this study was performed according to the previous experimental models established by SHOJADOOST et al. (2012). On day 15, birds from the groups T2, T3 and T4 received a 10 -fold dose of anticoccidial vaccine (HIPRACOX $^{\circledR}$, HIPRA, Spain). On days 18 to 20, all the challenged groups were orally gavaged once daily in the crop with $3 \mathrm{~mL}$ of actively growing culture (15 hours) of toxigenic C. perfringens $\left(10^{8}\right.$ $\mathrm{cfu} / \mathrm{mL}$ ). Birds in the control group received $3 \mathrm{~mL}$ of sterile thioglycollate medium. The toxigenic $C$. perfringens strain was obtained from the Veterinary Serum and Vaccine Research Institute (Cairo, Egypt). It was a type A field strain, isolated from a clinical case of NE and did not carry the netB gene, as verified by polymerase chain reaction (PCR).

Measurements. The parameters analyzed were body weight gain (BWG), feed intake (FI), feed conversion ratio (FCR), mortality, intestinal lesion score, and ileal $C$. perfringens enumeration by quantitative real-time PCR (qRT-PCR).

Growth performance and mortality. In order to assess the evolution of the BWG, the birds were individually weighed on days 0,15 and 28 . Thereafter, the average BWG of each group was calculated. FI was recorded for each replicate on days 15 and 28. Cumulative weight gain and feed consumption were determined, whereas FCR was calculated for the different periods (day 0-15, 15-28 
and 0 -28). The mortality of the birds was recorded on a daily basis.

Intestinal lesion score. Intestinal scoring was performed on days 21 and 28. Two birds randomly selected per replicate from each group were euthanized by cervical dislocation. The small intestine (duodenum, jejunum and ileum) was removed, spread and then totally opened longitudinally for notation of lesions. The scoring was done according to the scale described by DAHIYA et al. (2005). Briefly, 0: apparently normal; 1: thin-walled and friable intestines with small red petechiae $(>5) ; 2$ : focal necrotic lesions; 3: patches of necrosis ( 1 to $2 \mathrm{~cm}$ long); 4 : diffused necrosis typical of field cases.

Ileal $C$. perfringens enumeration by qRTPCR. The total population of $C$. perfringens was estimated in ileal contents by qRT-PCR on days 21 and 28. One gram of fresh ileal content from one bird per replicate for each group was collected into $2 \mathrm{~mL}$ sterile Eppendorf tubes, and immediately stored at $-20{ }^{\circ} \mathrm{C}$.

Genomic DNA was extracted from $200 \mathrm{mg}$ of ileal digesta using a QIAamp DNA Stool Mini Kit (QIAGEN, USA), as indicated by the manufacturer's instructions. The gene-specific primer sequence corresponding to the alpha toxin gene of $C$. perfringens, as reported by $\mathrm{YOO}$ et al. (1997), was procured from Midland Certified Reagent Company, (Oligos, USA). The details of primers are given in Table 2 .

For amplification reactions, a QuantiTect $^{\mathbb{B}}$ $\mathrm{SYBR}^{\circledR}$ green PCR kit (QIAGEN, USA) was used. The RT-PCR was performed on an MX3005P QPCR system (Stratagene, USA) according to the manufacturer's protocol. For quantification, standard curves were created using ten-fold serial dilutions of DNA extracted from $1 \mathrm{~mL}$ of a known count of $C$. perfringens. Regression analyses of the standard curves were used for estimating the amount of $C$. perfringens relative to the threshold cycle $(\mathrm{Ct})$ values (GREEN and SAMBROOK, 2012). Results were expressed as $\log _{10}$ genomic DNA copy number per gram of digesta.

Statistical analysis. The different results were described by the mean and the standard error (SE), calculated from the standard deviation (SD), according to the formula $\mathrm{SE}=\mathrm{SD} / \mathrm{n} 0.5$, where $\mathrm{n}$ is the number of replicates.

The homogeneity of the variance between treatments was verified by the Bartlett test. In cases where this test was significant $(\mathrm{P}<0.05)$, the means of the groups were compared by the nonparametric Mann-Whitney test and the Kruskal-Wallis test. When the Bartlett test was not significant $(\mathrm{P}>0.05)$, the results were subjected to a one-way analysis of variance (ANOVA 1) to determine the effect of the treatment on the parameters considered. The significance level chosen was at least 0.05.

All of these analyzes were done using the StatView program (Abacus Concepts, 1996, Inc., Berkeley, CA94704-1014, USA).

\section{Results}

The growth performance of the broiler chickens is summarized in Table 3. At the beginning of the trial (day 0), the chicks had a homogeneous weight: an average of $41.09 \pm 0.35 \mathrm{~g}$ (data not shown). The BWG was not affected by the dietary inclusion of probiotics for the whole trial period $(\mathrm{P}>0.05)$. At the end of the experiment, the infected groups showed increased FI and FCR compared to the control group; however, the supplementation of probiotics improved FI and FCR compared to the group infected with $C$. perfringens and coccidia. On the $28^{\text {th }}$ day, the FCR of groups T4 and T3 was significantly lower: $-12 \%$ and $-10 \%$, respectively compared to group T2 $(\mathrm{P}<0.05)$. No mortality was recorded in any of the treatment groups in this study.

As shown in Table 4, at necropsy on day 21, the lesion scores of the infected groups without supplementation had significantly increased, 7 and 4 times greater for groups T2 and T1, respectively, compared to the control group $(\mathrm{P}<0.0001)$. However, a significant decrease $(\mathrm{P}<0.0001)$ was observed in the lesion scores of the groups infected and supplemented with probiotics compared to group T2. On day 28 , the dietary inclusion of probiotics ( $P$. acidilactici or $S$. cerevisiaie) significantly decreased $(\mathrm{P}<0.0001)$ the lesion scores compared to group T2. Finally, no significant difference was recorded for lesion scores between groups T0, T3 and T4 on days 21 and 28. 
R. Merati et al.: The effects of Pediococcus acidilactici and Saccharomyces cerevisiae on broiler chickens challenged with Clostridium perfringens induced subclinical necrotic enteritis

Table 3. Body weight gain, feed intake and feed conversion ratio of broiler chickens measured during the experiment.

\begin{tabular}{|l|c|c|c|c|c|c|c|}
\hline Day 0 - 15 & T0 & T1 & T2 & T3 & T4 & SEM & P-value \\
\hline BWG $(\mathrm{g})$ & $226.77^{\mathrm{a}}$ & $226.20^{\mathrm{a}}$ & $225.33^{\mathrm{a}}$ & $249.40^{\mathrm{b}}$ & $271.73^{\mathrm{c}}$ & 7.25 & $<0.0001$ \\
\hline FI (g) & $371.77^{\mathrm{a}}$ & $393.18^{\mathrm{c}}$ & $383.70^{\mathrm{bc}}$ & $376.00^{\mathrm{ab}}$ & $387.43^{\mathrm{bc}}$ & 3.85 & 0.01 \\
\hline FCR & $1.68^{\mathrm{bc}}$ & $1.81^{\mathrm{c}}$ & $1.79^{\mathrm{c}}$ & $1.52^{\mathrm{ab}}$ & $1.46^{\mathrm{a}}$ & 0.06 & $<0.0001$ \\
\hline J15 - J28 \\
\hline BWG (g) & 576.67 & 550.39 & 537.89 & 552.89 & 541.56 & 22.12 & 0.86 \\
\hline FI (g) & $1002.11^{\mathrm{a}}$ & $1038.09^{\mathrm{b}}$ & $1035.11^{\mathrm{b}}$ & $1022.55^{\mathrm{b}}$ & $991.44^{\mathrm{a}}$ & 5.53 & $<0.0001$ \\
\hline FCR & 1.77 & 1.94 & 2.32 & 1.90 & 1.89 & 0.16 & 0.40 \\
\hline Cumulative & 802.33 & 779.07 & 742.56 & 803.50 & 806.17 & 21.49 & 0.26 \\
\hline BWG (g) & $1373.88^{\mathrm{a}}$ & $1431.28^{\mathrm{d}}$ & $1418.81^{\mathrm{cd}}$ & $1398.55^{\mathrm{bc}}$ & $1378.88^{\mathrm{ab}}$ & 7.98 & $<0.0001$ \\
\hline FI (g) & $1.72^{\mathrm{a}}$ & $1.86^{\mathrm{bc}}$ & $1.97^{\mathrm{c}}$ & $1.77^{\mathrm{ab}}$ & $1.73^{\mathrm{ab}}$ & 0.06 & 0.03 \\
\hline FCR
\end{tabular}

BWG: body weight gain; FI: feed intake; FCR: feed conversion ratio. ${ }^{\text {a-d }}$ Within the same row, means with different letters are significantly different. SEM: Standard Error of the Mean. T0: basal diet with no treatments; T1: basal diet with no additives $+C$. perfringens challenge; T2: basal diet with no additives $+C$. perfringens challenge + anticoccidial vaccine (overdose); T3: basal diet supplemented with $P$. acidilactici for the whole trial period $+C$. perfringens challenge + anticoccidial vaccine (overdose); T4: basal diet supplemented with of $S$. cerevisiae for the whole trial period $+C$. perfringens challenge + anticoccidial vaccine (overdose).

Table 4. Mean values of lesion scores recorded in broiler chickens at the age of 21 and 28 days

\begin{tabular}{|l|c|c|c|c|c|c|c|}
\hline & T0 & T1 & T2 & T3 & T4 & SEM & P-value \\
\hline Lesion score & $0.17^{\mathrm{a}}$ & $0.83^{\mathrm{b}}$ & $1.42^{\mathrm{b}}$ & $0.33^{\mathrm{a}}$ & $0.33^{\mathrm{a}}$ & 0.14 & $<0.0001$ \\
\hline Day 21 & $0.17^{\mathrm{a}}$ & $1^{\mathrm{b}}$ & $1.25^{\mathrm{b}}$ & $0.42^{\mathrm{a}}$ & $0.42^{\mathrm{a}}$ & 0.13 & $<0.0001$ \\
\hline Day 28
\end{tabular}

${ }^{\text {a,b }}$ Within the same row, means with different letters are significantly different. SEM: Standard Error of the Mean. T0: basal diet with no treatments; T1: basal diet with no additives $+C$. perfringens challenge; T2: basal diet with no additives $+C$. perfringens challenge + anticoccidial vaccine (overdose); T3: basal diet supplemented with $P$. acidilactici for the whole trial period $+C$. perfringens challenge + anticoccidial vaccine (overdose); T4: basal diet supplemented with $S$. cerevisiae for the whole trial period $+C$. perfringens challenge + anticoccidial vaccine (overdose).

Table 5. Ileal C. perfringens count in broiler chickens at the ages of 21 and 28 days (mean, $\log _{10}$ copies/g digesta)

\begin{tabular}{|l|c|c|c|c|c|c|c|}
\hline & T0 & T1 & T2 & T3 & T4 & SEM & P-value \\
\hline Day 21 & $0.00^{\mathrm{a}}$ & $7.24^{\mathrm{bc}}$ & $7.74^{\mathrm{b}}$ & $4.48^{\mathrm{a}}$ & $4.65^{\mathrm{ac}}$ & 0.64 & $<0.0001$ \\
\hline Day 28 & $0.00^{\mathrm{a}}$ & $7.55^{\mathrm{b}}$ & $8.09^{\mathrm{b}}$ & $2.13^{\mathrm{a}}$ & $3.32^{\mathrm{a}}$ & 0.69 & $<0.0001$ \\
\hline
\end{tabular}

${ }^{\text {a-c }}$ Within the same row, means with different letters are significantly different. SEM: Standard Error of the Mean. T0: basal diet with no treatments; T1: basal diet with no additives $+C$. perfringens challenge; T2: basal diet with no additives $+C$. perfringens challenge + anticoccidial vaccine (overdose); T3: basal diet supplemented with $P$. acidilactici for the whole trial period $+C$. perfringens challenge + anticoccidial vaccine (overdose); T4: basal diet supplemented of $S$. cerevisiae for the whole trial period + C. perfringens challenge + anticoccidial vaccine (overdose). 
Regarding ileal C. perfringens enumeration (Table 5), both on the $21^{\text {st }}$ and the $28^{\text {th }}$ day, the $C$. perfringens population significantly increased $(\mathrm{P}<$ 0.0001 ) by the $C$. perfringens challenge. However, the count of $C$. perfringens for the groups infected and supplemented with probiotics ( $P$. acidilactici or S. cerevisiaie) decreased significantly $(\mathrm{P}<0.0001)$ compared to the infected groups without probiotic supplementation.

\section{Discussion}

In our study, the results revealed a significant improvement in the BWG and FCR of broiler chickens who received a diet supplemented with probiotics ( $P$. acidilactici or $S$. cerevisiaie), before the inoculation of $C$. perfringens and the anticoccidial vaccine (on day 15), confirming the results of previous studies showing that probiotics have a potential role in improving growth performance (SANTIN et al., 2001; ZHOU et al., 2016; WANG et al., 2017).

After infection with an overdose of anticoccidial vaccine (on day 15) and inoculation of $C$. perfringens for 3 days, a significant increase in FCR was recorded for the challenged group with $C$. perfringens without supplementation of probiotics (T1) compared to the control group (T0). This negative effect of $C$. perfringens infection might be related to intestinal mucosa damage that may affect feed absorption, and thus utilization, resulting in decreased growth performance (DAHIYA et al., 2007). However, group T2 (inoculated with coccidia and clostridia, but not supplemented with probiotics) showed numerically higher FCR compared to group T1 (inoculated with clostridia, but not supplemented with probiotics). This suggests that the use of the anticoccidial vaccine as a predisposing factor is able to amplify the negative effects of $C$. perfringens infection. These results are in agreement with ABUDABOS and YEHIA (2013); ABUDABOS and ALYEMNI (2013) and EECKHAUT et al. (2016) who used the anticoccidial vaccine $\left(\right.$ Paracox $\left.^{\circledR}-8\right) 10$ times the dose associated with $C$. perfringens infection to reproduce NE, in order to test different treatments against this disease.
Comparing the groups infected and supplemented with probiotics ( $P$. acidilactici or $S$. cerevisiaie) to group $\mathrm{T} 2$, no significant difference was recorded for BWG. However, we noticed an improvement in FCR, related to a slight decrease in FI since growth was not affected. This reflects the better efficiency of conversion of the feed, which might be related to better intestinal absorption due to the probiotic's action. Previous studies have reported the same results. ABUDABOS and YEHIA (2013) concluded that the use of a $S$. cerevisiae yeast extract in a model of experimental infection by $C$. perfringens subjected to a predisposing factor (coccidia), can significantly improve the FCR of broiler chickens. In addition, M'SADEQ et al. (2015) reported that the use of the cell wall of the yeast $S$. cerevisiae in the diet of broiler chickens subjected to experimental NE, can improve growth performance. The beneficial effect of the yeast $S$. cerevisiae might be associated with the reduction of the stress reactions of birds by increasing the absorption of vitamins, the synthesis of enzymes, and the metabolism of proteins, thus allowing better digestion and absorption of nutrients, which results in improved growth performances.

The same results were observed for probiotic lactic acid bacteria. Several studies have reported a positive effect of their use on growth performance. A significant improvement in weight gain and FCR was recorded in a study on the effect of Bacillus subtilis supplementation in broiler chickens by TACTACAN et al. (2013). In addition, ZHOU et al. (2016) evaluated the effect of Bacillus licheniformis on the growth performance of broiler chickens experimentally infected with $C$. perfringens. They reported that its use can significantly improve weight gain and FCR, explaining that these effects are mainly attributed to the fact that Bacillus licheniformis can improve nutrient digestion, and their use by broilers, by producing several enzymes, such as lipase, protease and amylase.

In the current study, the challenge did not result in overtly clinical signs of NE and there were no mortalities associated with oral exposure to $C$. perfringens. However, the multiple oral gavages of $C$. perfringens associated with an over dose of anticoccidial vaccine affected the integrity of the 
intestinal mucosa, as observed by macroscopic lesions, which was the cause of an increased lesion score in group T2 compared to group T1 (inoculated with clostridia, not supplemented with probiotics), which itself had a significantly higher score compared to the control group (T0). These results are similar to previous studies using the same challenge model to create subclinical NE (ABUDABOS and YEHIA, 2013; DU et al., 2016; EECKHAUT et al., 2016; ZHOU et al., 2016), while the dietary inclusion of probiotics (P. acidilactici or $S$. cerevisiaie) decreased macroscopic gut lesions compared to group T2. Our data agree with previous investigations who tested several probiotics (lactic acid bacteria, yeast) and reported that their use can have a beneficial effect in protection against the appearance of lesions caused by $C$. perfringens induced subclinical NE in broiler chickens (KNAP et al., 2013; TACTACAN et al., 2013; M'SADEQ et al., 2015; XUE et al., 2017). This beneficial effect might be related to the ability of these probiotics to enhance immunity, improve the development of intestinal microflora and produce lactic acid, making the intestinal environment unfavorable for the development of pathogens, thus decreasing their negative impact on intestinal health (TITBALL et al., 1999).

The results obtained from ileal $C$. perfringens count at 21 and 28 days of age clearly showed an overgrowth of $C$. perfringens in the gut of the challenged broiler chickens compared to the control group. This is in agreement with the work of TOSI et al. (2013) who reported that the challenged group without supplementation demonstrated a high level of $C$. perfringens population. However, the dietary inclusion of probiotics ( $P$. acidilactici or $S$. cerevisiaie) had a positive effect on the control of the overgrowth proliferation of the $C$. perfringens population, as related to group $\mathrm{T} 2$. This might be associated with their antimicrobial properties which are linked to their effect on toxins derived from pathogens, such as the secretion of proteases that act on the alpha toxin produced by $C$. perfringens (TITBALL et al., 1999), or the production of bacteriocins that are active against different Clostridium strains, thereby reducing their proliferation (TEO and TAN, 2005).

\section{Conclusions}

The results of the current study show that the use of an anticoccidial vaccine at 10 times the dose associated with oral exposure to $C$. perfringens allowed experimental reproduction of subclinical NE. The infection resulted in impairment of feed conversion, an increased lesion score $(\leq 2)$ and overgrowth of the $C$. perfringens population. Furthermore, dietary supplementation with probiotics ( $P$. acidilactici or $S$. cerevisiae) could be beneficial to alleviate the negative effects of subclinical NE in broiler chickens, because of the significant improvement in feed conversion, the net reduction of gut lesions, as well as the decrease in the intestinal $C$. perfringens population.

\section{Conflict of interest}

The authors confirm that the data presented do not represent any conflict of interest.

\section{Acknowledgements}

The authors thank the staff of the laboratory of hygiene and animal pathology, University of Tiaret, especially Mr Abdali Mostapha for their excellent technical support. We are also grateful to Dr Khettou Mohamed (Export Manager Africa \& Middle East for Lallemand Animal Nutrition S.A., Blagnac, France) for the free supply of the probiotics. This study was conducted under the patronage of the general direction of scientific research and technological development of Algeria.

\section{References}

ABUDABOS, A. M., A. H. ALYEMNI (2013): Effects of the Essential Oil Blend CRINA ${ }^{\circledR}$ Poultry in feed on broiler performance and gut microbiology. Ital. J. Anim. Sci. 12. 513- 517.

DOI: $10.4081 /$ ijas.2013.e83

ABUDABOS, A. M., H. M. YEHIA (2013): Effect of dietary mannan oligosaccharide from Saccharomyces cerevisiae on live performance of broilers under Clostridium perfringens challenge. Ital. J. Anim. Sci. 12 231-235.

DOI: 10. 40 81/ijas.2013.e38

CALY, D. L., R. D'INCA, E. AUCLAIR, D. DRIDER (2015): Alternatives to antibiotics to prevent necrotic enteritis in broiler chickens: A Microbiologist's Perspective. Front. Microbiol. 6, 1336.

DOI: $10.3389 /$ fmicb.2015.01336.

DAHIYA, J. P., D. HOEHLER, D. C. WILKIE, A. G. VAN KESSEL, M. D. DREW (2005): Dietary glycine concentration affects intestinal Clostridium perfringens 
R. Merati et al.: The effects of Pediococcus acidilactici and Saccharomyces cerevisiae on broiler chickens challenged with Clostridium perfringens induced subclinical necrotic enteritis

and lactobacilli populations in broiler chickens. Poult. Sci. $84,1875-1885$.

DOI: 10.1093 /ps/ 84.12.1875

DAHIYA J. P., D, HOEHLER, A. G. VAN KESSEL, M. D. DREW (2007): Dietary encapsulated glycine influences Clostridium perfringens and Lactobacilli growth in the gastrointestinal tract of broiler chickens. J. Nutr. 137 (6), 1408-1414.

DOI: $10.1093 / \mathrm{jn} / 137.6 .1408$

DU, E., W. WANG, L. GAN, Z. LI, S. GUO (2016): Effects of thymol and carvacrol supplementation on intestinal integrity and immune responses of broiler chickens challenged with Clostridium perfringens. J. Anim. Sci. Biotechnol. 7, 19.

DOI: $10.1186 / \mathrm{s} 40104-016-0079-7$

EECKHAUT, V., J. WANG, A. VAN PARYS, F. HAESEBROUCK, M. JOOSSENS, G. FALONY, J. RAES, R. DUCATELLE, F. Van Immerseel (2016): The probiotic Butyricicoccus pullicaecorum reduces feed conversion and protects from potentially harmful intestinal microorganisms and necrotic enteritis in broilers. Front. Microbiol. 7, 1416.

DOI: $10.3389 /$ fmicb.2016.01416

GAUCHER, M. L (2016): Study of the impact of two treatments, including one without antibiotics, on digestive health and Clostridium perfringens populations in broiler farms PhD Thesis. Veterinary medicine Faculty, Montreal University, Canada (in French).

GREEN, M. R., J. SAMBROOK (2012): Molecular Cloning. A Laboratory Manual. $4^{\text {th }}$ ed. Vol 1, Cold Spring Harbor Laboratory Press, New York, p. 1885.

HUME, M. E. (2011): Historic perspective: prebiotics, probiotics, and other alternatives to antibiotics. Poult. Sci. 90, 2663-2669.

DOI: $10.3382 /$ ps.2010-01030

JUKES, T. H., D. C. HILL, H. D. BRANION (1956): Effect of feeding antibiotics on the intestinal wall of the chick. Poult. Sci. 35, 716-723.

DOI: $10.3382 / \mathrm{ps} .0350716$

KNAP, I., B. LUND, A. B. KEHLET, C. HOFACRE, G. MATHIS (2013): Bacillus licheniformis prevents necrotic enteritis in broiler chickens. Avian. Dis. 54, 931-935.

DOI: 10.1637/9106-101509-ResNote.1

M'SADEQ, S. A., S. B. WU, M. CHOCT, R. FORDER, R. A. SWICK (2015): Use of yeast cell wall extract as a tool to reduce the impact of necrotic enteritis in broilers. Poult. Sci. 94, 898-905.

DOI: $10.3382 / \mathrm{ps} /$ pev035

O'BRIEN, T. F (2002): Emergence, spread, and environmental effect of antimicrobial resistance: how use of an antimicrobial anywhere can increase resistance to any antimicrobial anywhere else. Clin. Infect. Dis. 34, S78-S84. DOI: $10.1086 / 340244$
SANTIN, E., A. MAIORKA, M. MACARI, M. GRECCO, J. C. SANCHEEZ, T. M. OKADA, A. M. MYASAKA (2001): Performance and intestinal mucosa development of broiler chickens fed diets containing Saccharomyces cerevisiae cell wall. J. Appl. Poult. Res. 10, 236-244.

DOI: $10.1093 /$ japr/10.3.236

SHOJADOOST, B., A. R. VINCE, J. F. PRESCOTT (2012): The successful experimental induction of necrotic enteritis in chickens by Clostridium perfringens: a critical review. Vet. Res. 43,74.

DOI: $10.1186 / 1297-9716-43-74$

SKINNER, J. T., S. BAUER, V. YOUNG, G. PAULING, J. WILSON (2010): An economic analysis of the impact of subclinical (mild) necrotic enteritis in broiler chickens. Avian Dis, 54, 1237-1240.

DOI: 10.1637/9399-052110-Reg.1

TACTACAN, G. B., J. K. SCHMIDT, M. J. Miille, D. R. JIMENEZ (2013): A Bacillus subtilis (QST 713) sporebased probiotic for necrotic enteritis control in broiler chickens, J. Appl. Poult. Res. 22, 825-831.

DOI: 10.33 82/ japr.2013-00730

TEO, A. Y., H. TAN (2005): Inhibition of Clostridium perfringens by a novel strain of Bacillus subtilis isolated from the gastrointestinal tracts of healthy chickens. Appl. Environ. Microbiol. 71, 4185-4190.

DOI: 10.1128/AEM.71.8.4185-4190.2005

TIMBERMONT, L., F. HAESEBROUCK, R. DUCATELLE, F. VAN IMMERSEEL (2011): Necrotic enteritis in broilers: an updated review on the pathogenesis. Avian. Pathol. 40, 341-347.

DOI:10.1080/03079457.2011.590967

TITBALL, R. W., C. E. NAYLOR, A. K. BASAK (1999): The Clostridium perfringens alpha toxin. Anaerobe. 5, 51-64.

DOI: 10.1006/anae.1999.0191

TOSI, G., P. MASSI, M. ANTONGIOVANNI, A BUCCIONI, S MINIERI, L. MARENCHINO, M. MELE (2013): Efficacy test of a hydrolysable tannin extract against necrotic enteritis in challenged broiler chickens. Ital. J. Anim. Sci. 12, 392-395.

DOI: 10.4081/ijas.2013.e62

VAN IMMERSEEL, F., J. I. ROOD, R. J. MOORE, R. W. TITBALL (2009): Rethinking our understanding of the pathogenesis of necrotic enteritis in chickens. Trends. Microbiol. 17, 32-36.

DOI: $10.1016 /$ j.tim.2008.09.005

WANG, H., X. NI, X. QING, D. ZENG, M. LUO, L. LIU, G. LI, K. PAN, B. JING (2017): Live probiotic Lactobacillus johnsonii BS15 promotes growth performance and lowers fat deposition by improving lipid metabolism, intestinal development, and gut microflora in broilers. Front. Microbiol. 8, 1073.

DOI: $10.3389 /$ fmicb.2017.01073 
R. Merati et al.: The effects of Pediococcus acidilactici and Saccharomyces cerevisiae on broiler chickens challenged with Clostridium perfringens induced subclinical necrotic enteritis

XUE, G. D., S. B. WU, M. CHOCT, R. A. SWICK (2017): Effects of yeast cell wall on growth performance, immune responses and intestinal short chain fatty acid concentrations of broiler in an experimental necrotic enteritis model. Anim. Nutr. 3, 399-405.

DOI: 10.1016/j.aninu.2017.08.002

YOO, H. S., S. U. LEE, K. Y. PARK, Y. H. PARK (1997): Molecular typing and epidemiological survey of prevalence of Clostridium perfringens Types by Multiplex PCR. J. Clin. Microbiol. 35, 228-232.
ZHOU, M., D. ZENG, X. NI, T. TU, Z. YIN, K. PAN, B. JING (2016): Effects of Bacillus licheniformis on the growth performance and expression of lipid metabolism-related genes in broiler chickens challenged with Clostridium perfringens-induced necrotic enteritis. Lipids. Health. Dis. $15,48$.

DOI: $10.1186 / \mathrm{s} 12944-016-0219-2$

MERATI, R., A. A. A.-F. MOHAMED, Z. BERRAMA, H. AGGAD, A. HAMMOUDI, S. TEMIM: Učinak Pediococcus acidilactici i Saccharomyces cerevisiae na brojlere sa supkliničkim nekrotičnim enteritisom izazvanim bakterijom Clostridium perfringens. Vet. arhiv 91, 389-397, 2021.

\section{SAŽETAK}

Cilj ovog istraživanja bio je procijeniti učinke Pediococcus acidilactici (P. acidilactici) i Saccharomyces cerevisiae (S. cerevisiae) na prirast, intestinalne lezije i količinu bakterija Clostridium perfringens $(C$. perfringens) u crijevu brojlera sa supkliničkim nekrotičnim enteritisom izazvanim bakterijom C. perfringens. Ukupno 150 brojlera podijeljenih u pet pokusnih skupina (6 replikacija u svakoj skupini, 5 pilića po replikaciji, 6 kaveza po skupini) uzgajano je u kavezima 29 dana: T0 (kontrolna skupina, neinficirani, bez dodatka prehrani); skupina T1 (inficirani bakterijom C. perfringens, bez dodatka prehrani); skupina T2 (inficirani bakterijom C. perfringens i kokcidijom, bez dodatka prehrani); skupina T3 (inficirani bakterijom C. perfringens i kokcidijom, s dodatkom P. acidilactici); skupina T4 (inficirani bakterijom C. perfringens i kokcidijom, s dodatkom S. cerevisiae). Analizirani pokazatelji bili su porast tjelesne mase, unos hrane, stopa konverzije hrane, smrtnost, intestinalne lezije i količina bakterije $C$. perfringens u crijevu mjerena kvantitativnim PCR testom u stvarnom vremenu. Rezultati su bili smanjenje stope rasta, porast ozljeda $(\leq 2)$ i prekomjeran porast bakterija $C$. perfringens. Uvođenje $P$. acidilactici ili $S$. cerevisiae u prehranu znakovito je poboljšalo stopu konverzije hrane, smanjilo crijevne lezije te smanjilo broj bakterija $C$. perfringens $\mathrm{u}$ crijevu. Zaključno, rezultati upućuju na to da bi dodatak probiotika (P. acidilactici ili $S$. cerevisiae) mogao smanjiti negativne učinke supkliničkog nekrotičnog enteritisa u brojlera.

Ključne riječi: Clostridium perfringens; nekrotični enteritis; Pediococcus acidilactici; Saccharomyces cerevisiae; brojleri 
